us that it was a mere outburst of German humor, and all joined in a hearty laugh over the poor fellow's discomfiture.

Professor Jellinek's fame as a teacher and publicist drew to Heidelberg students from nearly all quarters of the globe. His seminary was probably one of the most cosmopolitan in Europe. The one attended by the writer consisted, if memory serves aright, of a Polish duke, the son of a Turkish ambassador, a Servian, a Bulgarian, one or two. Japanese, a few Russian Jews, several Swiss and Austrians, three Americans, and possibly half a dozen Germans.

It was in truth a rare gathering of choice spirits. The utmost freedom of discussion and debate prevailed. "How is it in Japan, in Switzerland, in Russia, in America?" the professor would ask. Each made his contribution to the common stock. No detail was too small, no idea too crude, no thought or expression too obscure or involved to be eagerly grasped, analyzed, weighed or condensed and made to do its proper work by the master's keen, penetrating, profound intellect.

To those whom he admitted to his intimacy, Professor Jellinek also revealed the charm of a rich and rare personalty. Always accessible, candid, and outspoken, he showed an expansive and lovable nature. In the sanctuary of his own study or in the course of promenades among the lovely environs of Heidelberg, he manifested interest in small things as well as great, canvassed the personal tastes and experiences of his favorite students, exhibited an affectionate and even tender solicitude for their welfare, and spurred them on to noble achievement.

\title{
PRESIDENT TAFT ON INTERNATIONAL PEACE
}

For more than a year past President Taft has expressed himself strongly in favor of international peace and the means and instrumentalities by which peace, which fortunately exists between nations, may be preserved. From theoretical advocacy of the cause, he is now endeavoring to conclude treaties with foreign nations, especially Great Britain, France and Germany, by which the contracting parties pledge themselves to the peaceful settlement of all international controversies which may arise between them, so that war, if not wholly unthinkable, will be at least a remote possibility between these various countries.

It was to be expected that his training as a lawyer would prejudice him in favor of that mode or adjusting disputes which the common sense ot mankind has adopted within national lines; that his experience as a 
Federal judge, passing upon questions to which citizens of different States were parties, would show him the ease with which State lines could be eliminated from the controversy if only the litigants wished judicial settlement. His experience as Secretary of War had no doubt shown him the large and constant preparation made for possible rather than probable wars which every reasonable man hoped to avoid, and the vast sums of money spent upon equipment which it was hoped would never be used and which in all probability will not be used, no doubt caused him to revert to his training as lawyer and judge in order to see if the conflicts which many feared could not be averted by peaceable means.

In one sense of the word, the President's attitude is not at all strange or surprising, because the views which he expressed are undoubtedly those held by the majority of law-abiding American citizens; but it is remarkable that the chief executive of a country, even an American president, should seek to raise international peace to the rank of a public issue and should devote not merely a large portion of his scant leisure to the elaboration of plans for peaceful settlement of international disputes, but should on public occasions, at banquets, before peace societies, in commemorative addresses, addresses on national holidays, such as Decoration Day, and before veterans of the Civil War, proclaim the advantages of international peace, and call upon his immediate audience and the general public to aid him in rendering the resort to force as impossible as it is from the larger aspect unreasonable. As the President said in his address before the American Peace and Arbitration League in New York City, March 22, 1910 :

The truth is that the subject does not offer much opportunity for variety. We are all in favor of virtue; we are all in favor of goodness, and we are all in favor of peace; and as peace can be best maintained by arbitration and conciliation, of course we are in favor of it, - in favor of resorting to arbitration rather than to war. I say we all are, but I know there are some gentlemen who * * * favor war as a necessary treatment of a nation in order to develop its finest qualities, and I am not disposed to say that as we look back in history, some of the most dreadful wars in history, notably that of our Civil War, could hardly have been avoided if we were to accomplish the good which that war did accomplish. But as a general thing we are all opposed to war, because war is hell. And when you have said that, and said that any means of avoiding it by arbitration or conciliation is to be sought, it seems to me that it is difficult to arouse a controversy on the subject.

After speaking of the expense of war and the humiliation of defeat, and advocating a permanent court of arbitration to which all controver- 
sies can be referred, the President referred to arbitration treaties and made the following pronouncement which is likely to prove epoch-making in the matter of treaties of arbitration:

I have noticed exceptions in our arbitration treaties, as to reference of questions of honor, of national honor, to courts of arbitration. Personally, I do not see any more reason why matters of national honor should not be referred to a court of arbitration any more than matters of property or matters of national proprietorship.

I know that is going further than most men are willing to go, but as among men, we have to submit differences even if they involve honor, now, if we obey the law, to the court, or let them go undecided. It is true that our courts can enforce the law, and as between nations there is no court with a sheriff or a marshal that can enforce the law. But I do not see why questions of honor may not be submitted to a tribunal supposed to be composed of men of honor who understand questions of national honor, to abide by their decision, as well as any other question of difference arising between nations.

In an important address delivered at the banquet of the American Society for Judicial Settlement of International Disputes, held at Washington on December 1\%, 1910, the President took a long step in advance. In the first place he stated that, in his opinion, the establishment of a permanent court of arbitration was the only means of reducing armament. In the next place, he declared himself ready to negotiate with the nations treaties of arbitration in which vital interests and questions of honor should be included, an offer which was eagerly accepted by Great Britain and France and which led to the negotiation of the general treaty with Great Britain which is shortly to be submitted to the Senate for its advice and consent. The exact language of the President, however, should be quoted:

I am strongly convinced that the best method of ultimately securing disarmament is the establishment of an international court and the development of a code of international equity which nations will recognize as affording a better method of settling international controversies than war. We must have some method of settling issues between nations, and if we do not have arbitration, we shall have war. Of course, the awful results of war with its modern armaments and frightful cost of life and treasure, and its inevitable shaking of dynasties and governments, have made nations more chary of resort to the sword than ever before; and the present, therefore, because of this, would seem to be an excellent time for pressing the substitution of courts for force.

After expressing himself in favor of the international prize court and urging the establishment of the court of arbitral justice, and stating positively that the actual settlement of disputes by courts of arbitration 
is the best means of advancing the cause, the President concluded this part of his address with an offer to conclude unrestricted treaties of arbitration:

If now we can negotiate and put through a positive agreement with some great nation to abide the adjudication of an international arbitral court in every issue which can not be settled by negotiation, no matter what it involves, whether honor, territory, or money, we shall have made a long step forward by demonstrating that it is possible for two nations at least to establish as between them the same system of due process of law that exists between individuals under a government.

In the interval between March and December, the President's views seem to have crystallized. He no longer expressed himself as theoretically in favor of peace and arbitration, but he shows by apt illustration the benefits which international courts would produce and the prerequisites to the successful operation of such courts. That is to say, the establishment of an international court tends to disarmament, and that as a prerequisite to the successful operation of such a court a code of international equity must be created, and that to supply the court when created and endowed with a code of equity, unrestricted treaties of arbitration must be concluded which bind nations to submit their controversies when and as the $y$ arise.

A few months later, President Taft delivered an address at Arlington Cemetery on Memorial Day (May 30, 1911). It would havębeen natural on such an occasion even for a pacifist to deal gently with war, to speak of the benefits which follow in its train, to justify the war for the preservation of the Union, and to eulogize the heroic dead. Not so President Taft. President Taft was not unmindful of the services rendered by the soldiers in the Civil War, but he is oppressed by the loss of life and is anxious to prevent war in the future, with its needless sacrifice of life, energy and national resources. He said:

As we stand, however, in the presence of the dead on this beautiful May morning and seek to realize and enjoy the essence of patriotism which, like incense, steals into the atmosphere of this sacred spot, we find ourselves slipping into a conception of war as necessary to human development, the making of human character and the exhibition of the highest human ideals. We lose sight of the cruelty, the carnage, the arousing of the most brutal passions, the indifference to human suffering, the meanest human ambitions, the ghoulish corruption and an the other wickedness that follows in the trail of war, and we think only of the calm spirit of supreme self-sacrifice that ennobled the brave soldier who lost his life in the shock of battle and who rests peacefully with his comrades in these beautiful shades. 
Of course, it is necessary that we should have sin and temptation if we would have exhibitions of virtue which resist them, but is that a reason for favoring either temptation or sin? Of course, in order that we should know the existence and power of the highest traits of the human soul we must have human tragedies, but certainly no one would promote a tragedy for the purpose of furnishing to the world proof of the existence of such traits. Strive as we may to prevent or destroy them, we shall have sin and wickedness and temptation and tragedy enough, as a school of experience, development and demonstration of human character. The same answer must be made to those who permit themselves to advocate war as a necessary experience in the development of man.

Far be it from me to minimize in any way by these suggestions the debt we owe to the men buried here who carried on the successful struggle that resulted in the abolition of the cancer of slavery and which seemed ineradicable save by such an awful slaughter of the brightest and bravest and best of the nation's youth and manhood.

I shall not stop to discuss whether it might have been possible to accomplish the same great reform by milder methods. Whether that be true or not, the supreme sacrifice of these men, who lie about us, in the cause of advancing humanity can never be lessened or obscured by such a suggestion. But the thought at which $I$ would but hint this morning is that even in the hallowed presence of these dead, whose ideals of patriotism and love of their countrymen it needed a war to make everlastingly evident, we should abate no effort and should strain every nerve and avail ourselves of every honorable possible device to avoid war in the future.

I am not blind to the aid in creating sturdy manhood that the military discipline we see in the standing armies of Europe and in the regular army of this country furnishes, nor do. I deny the incidental benefits that may grow out of the exigencies and sequels of war. But when the books are balanced, the awful horrors of either internecine or international strife far outweigh the benefits that may be traced to it.

Let us leave this beautiful City of the National Dead, therefore, with the deepest gratitude to the men whose valorous deeds we celebrate, and whose memories we cherish, with the tenderest appreciation of the value of the examples they set, but with a determination in every way possible, consistent with honesty and manly and national self-restraint, to avoid the necessity for the display of that supreme self-sacrifice that we commemorate to-day in them.

In an address delivered on the eve of Independence Day in the Soldiers' Home at Marion, Indiana, President Taft had the moral courage to analyze the foreign wars to which the United States has been a party and to state, in his measured judgment, that the question involved in each was justiciable and might have been settled by recourse to arbitration. Thus, in speaking of the three foreign wars of the United States, and with an expression of doubt as to the Civil War, the President said: 
The War of 1812 might certainly have been avoided by arbitration. The questions there presented were questions all of which have been settled, by the judgment of mankind, in favor of our side of the controversy.

The War with Mexico - though there is some dispute over this - was one the questions of which were capable of solution by an impartial tribunal. Whether the Civil War could have been avoided is a very difficult question to answer. When slavery has become imbedded in the social fibre of a country, it is possible that only an excision of a war knife can remove the cancer.

Nor shall I attempt to answer a similar question as to the Spanish War. It is one of those instances of internal dissension like the Civil War; and yet I believe that the submission of the issues to a tribunal might have affected Spain's treatment of Cuba in such a way that we could have avoided a resort to arms.

It is doubtful if history records another instance of a chief executive referring to the foreign wars in which his country has been involved and in a public address before an association of veterans, on the eve of the celebration of the nation's independence, in which he quietly, manfully and impressively stated that all the foreign wars of his country might have been avoided by arbitration. The conclusion of his address is hardly less remarkable, for, after speaking of the general treaty of arbitration with Great Britain which he hoped to conclude, he said:

I am not a wild enthusiast or a blind optimist. I do not look forward to a complete restoration of peace which can not be disturbed in the world even if these treaties are adoptd. Morality of nations improves only step by step, and so the making and confirming of these treaties must be regarded only as a step, but as a very long step toward the securing of peace in the world. To you men who have seen war, to you who knew its horrors, I appeal for the support of every practical instrument like this in making war less possible and peace more permanent.

In the most recent address which President Taft has delivered so far, namely, the address before the Christian Endeavor Convention, held at Atlantic City, N. J., on July 8th, the President thus summarized the progress which has been made in the present generation and the means which are likely to make war less frequent in the future:

In the last twenty-five years we have made great progress toward an international condition in which war is less likely than heretofore. Under the inspiration of a common desire for peace, treaties have been made with reference to arbitration and for the establishment of a court at The Hague for the settlement of international disputes. We have ameliorated the ancient cruelties of war by Red Cross agreements. Now we are agreeing upon what is called the Declaration of London, which, if confirmed, as it seems likely to be, will take away from war on the sea those principles of lawful piracy that have always characterized the dealing with private property of the citizens of enemies. 
Every movement which tends to discourage war, and to furnish a means of avoiding it, ought to receive, and does receive, the earnest support of an organization that has the purposes and principles that actuate the society of the Christian Endeavor.

It is, therefore, not without reason that President Taft is popularly termed the "Peace President," although he has had competitors for the title among his distinguished predecessors. Thus, our first President sacrificed his popularity to maintain peace with Great Britain, and among his writings are to be found statements in favor of peace which can not be surpassed, although they may be equalled. Of the many, two are selected for quotation. On July 25, 1785, writing to David Humphreys, secretary of a commission sent abroad to negotiate treaties of commerce, General Washington said:

My first wish is to see this plague of mankind [war] banished from the earth, and the sons and daughters of this world employed in more pleasing and innocent amusements, than in preparing implements and exercising them for the destruction of mankind.1

On October 7th of the same year, he said, in a letter to a companiun of arms, then commander of a French army corps:

I never expect to draw my sword again. I can scarcely conceive the cause that would induce me to do it. * * * My first wish is ** * to see the whole world in peace, and the inhabitants of it as one band of brothers striving who should contribute most to the happiness of mankind.2

The victor of Appomatox was by training and experience a man of war, and he cut his path to the presidency by the sword. He might have been pardoned had he seen some virtue in war, yet General Grant, by his firm stand against war, prevented hostilities between Spain and the United States over the unspeakable atrocities of the Virginius case. Again, although the United States was in possession of a well-trained army, and although the soldiers of the South as well as those of the North would have willingly served against Great Britain, and although we had an invincible navy which boasted a Farragut, President Grant dismissed from his mind the possibilities of war and secured the peaceful settlement of the Alabama claims by the Geneva Tribunal. This soldier's confession of faith in arbitration and an international court has

1 Ford's Writings of George Washington, Vol. X, p. 473.

2 Spark's Writings of George Washington, Vol. IX, pp. 138, 139. 
certainly never been surpassed. Thus, in a letter written in December, 1879, to the Universal Peace Union, General Grant said:

Although educated and brought up as a soldier, and probably having been in as many battles as any one, certainly as many as most people could have been, yet there was never a time nor a day when it was not my desire that some just and fair way should be established for settling difficulties, instead of bringing innocent persons into the conflict, and thus withdrawing from productive labor able-bodied men, who, in the large majority of cases, have no particular interest in the subject for which they are contending. I look forward to the day when there will be a court established that shall be recognized by all nations, which will take into consideration all differences between nations and settle by arbitration or decision of such court these questions.

To be the worthy successor of Washington and Grant is an honor vouchsafed to but few men.

STATEMENT BY THE PRESIDENT OF THE I'RIBUNAL THAT THE NORTH ATLANTIC FISHERIES AWARD WAS A COMPROMISE

In an interesting article entitled "Formation of the Hague Court of Arbitration," published in Das Recht on March 10, 1911, the wellknown Austrian publicist and arbitrator, Professor Lammasch, says:

Already experience has shown that almost without exception the persons called to act as judges of the Hague Court either possess a distinguished name in the theory of public law or belong to the highest magistracy, and that in the matter of awards, some contain keen and penetrating holdings of a juridical nature. Especially was this the case in the three awards in which the writer of this article was President of the Tribunal: the Mascat case between Great Britain and France, the Orinoco case between the United States of America and Venezuela, and the Newfoundland and Canadian Fisheries case between Great Britain and the United States of America. To be sure the judgment in the last named case also contained elements of a compromise for which, however, the Tribunal had received special and exceptional authorization.

It is not the purpose of this editorial to comment upon this admission of the learned president of the tribunal, who speaks with full knowledge of the circumstances attending the award, but to call attention to it and the grounds upon which it is sought to be justified. The general arbitration treaty of April 4, 1908, between Great Britain and the United States ${ }^{1}$ pledges the contracting parties to refer to the Permanent Court

1 Printed in Supplement. 2:298. 